\title{
A History of Modern Yemen
}

Dresch, Paul. Cambridge, UK:

Cambridge University Press, 2000. 285 pages.

If you have time to read a single book on Yemen's recent past, Paul Dresch's A History of Modern Yemen is the one for you. Dresch, a University Lecturer at Oxford University's Institute of Social and Cultural Anthropology, elucidates the history of Yemen, starting in the 19th Century, with the British and the Ottomans vying for power and influence in this most ancient and original of Arab states, and culminating in Yemen's unification in 1990 and the Yemen-Saudi border settlement of 2000. Within these 285 pages, the author traces over a century and a half of the events and trends, men and movements, that have shaped today's Yemen. '

1. I say "men and movements" because all the players Dresch talks about are men. Dresch neglects to mention specific women who played a public, visible role (if any did). He aiso excludes information on the life of Yemeni women in general. 
To be sure, a thorough familiarity with Yemen's long history - if such knowledge lies within reach - would require a lifetime of reading and study. And Dresch's Modern Yemen does not pretend to cover such a span. What Dresch does cover, nevertheless, he covers well and offers a fascinating account not just for historians and Middle East analysts, but for Yemenophiles such as the present reviewer.

The author divides the book into seven chapters, along with two appendices, a glossary of Arabic terms, a chronological outline of Yemeni history since 1831, copious notes and references, and an index. Chapter One, "Turkey, Britain and Imam Yahya: the Years Around 1900", sets the stage not just for the anti-imperialist rebellions which would culminate in the mid-twentieth century, but also for the on-going internal struggles fought along tribal, regional, sectarian, and political lines. To follow the plethora of personalities, tribes, and place names which populate these pages can be a daunting task: prepare to jot down notes unless you own a photographic memory!

If the first chapter introduces us to the uneasy triangle of opposing aspirations among the Ottoman Turks, the Zaydi Imamate, and the British empire, Chapter Two, "Yahya and the British: 1918-1948" delves more deeply into the dynamics of the struggle between the latter two. By 1919, the Turks had quit Yemen, and Imam Yahya raced with the British to fill the vacuum. While the British held Aden with a tenacious grip and other parts of the South and South-East much more tenuously, a new "old" contender, the Saudis, entered the scene from the North and took control of the Asir. At the same time, political groupings and movements modernist, traditionalist, and regional - began to ferment throughout the country. The chapter ends with the assassination of Imam Yahya at the hands of Bani Hushaysh tribesmen. With Yahya's son Ahmad at the helm in Ta'iz, a would-be revolution was routed before it hardly had a chance to gain momentum.

Yet another player, Egypt's Gamal Abd al-Nasser, leaps onto the stage in Chapter Three, "A New Form of Politics: the 1950's". From 1952, Yemen and the entire Arab World "became subject to the nationalist rhetoric of Gamal Abd al-Nasser, whose influence would be difficult to overstate." Difficult to overstate, yet Nasser's aims defy over-simplification. Yes, the Egyptians arrived in Yemen to further the Arab nationalist revolution, and to expel the British from the South (and to counter Saudi expansion in the North), yet in a certain fundamental way, at least as Dresch sees it, 
Cairo and London both faced common enemies within Yemen: the forces of tradition. The latter ran out of steam - at least temporarily - to stem the revolution, and Chapter Three closes with the declaration in the North of the Yemen Arab Republic (YAR.), 26 September 1962.

"Through the 1960's Yemen was trapped in overlapping wars." Chapter Four, "Revolutions and Civil Wars: the 1960s", tries to make sense of this turbulent period. The Northern Republic fought armed opposition, not that the detractors yearned for the return of the Imamate, but rather because they saw the government in Sanaa as a puppet of Egypt. By 1965, Nasser had stationed 60,000 Egyptian troops in Yemen. At the same time, antiBritish resistance heated up in the South to such an extent that the British declared their intention to quit Aden, which they finally did at the end of 1967 . This chapter concludes with a newly formed - and perpetually unstable - government in Aden declaring a socialist state.

Chapter Five, "Two Yemeni States in the 1970's", offers us a peak at the parallel but distinct political and economic developments in the North and the South. The People's Democratic Republic (PDRY) of Yemen never succeeded in drawing the popular support of the masses of workers and peasants. According to Dresch, as hard as the regime in Aden tried to impose socialism, the toiling masses never prospered and the government seldom enjoyed long periods of stability or popularity. Northern rule, meanwhile, fared only slightly better. While the $40 \%$ literacy rate in the South was double that of the North, the YAR's economy thrived more than that of the PDRY. Yemenis by the hundreds of thousands from both sides of the border found work with their oil-rich neighbors to the north and in the Gulf states, while leaders from the two Yemens initiated tentative talks of unity. By 1979, North and South "seemed obviously, at a great many levels now and to citizens on both sides, one country with two governments."

While it is in the fifth chapter that we first meet Ali Abdullah Salih, a YAR major in command at Ta'iz during the mid-1970s, he returns, this time as President, in Chapter Six, "Yemen in a Wider World: Politics and Economics through the 1980s". Though the author sets the chapter in the context of a particular decade, he pursues the themes mentioned in the title, rather than historical events. For example, we learn here about the policies of the YAR's General Popular Congress (GPC) and its leader, Ali Abdullah Salih, and the mounting fortunes of the Military Economic Corporation (MECO), a public-private venture from which the President and his circle 
profit enormously to this day. Nor was the leadership of the PDRY immune to corruption: "Tensions in the South soon focused on the image of a state within the state, where money, cars, and buildings seemed all in the hands of [President] Ali Nasir's friends.” In 1986, thousands died in factional street-fighting in Aden and beyond. Despite the attempts of Ali Salim alBid (head of the Yemeni Socialist Party in the PDRY) to pick up the pieces after the bloodshed, he could see the writing on the wall: unity with the North was the PDRY's only hope.

The recent history of Yemen culminates in the unification of 1990, the Civil War of 1994, and the Yemen-Saudi border settlement of 2000, all concisely narrated and interpreted in the seventh and final chapter, "Yemen as a Single State". In this, as in the preceding chapters, Dresch does much more than merely chronicle the unfolding of Yemen's development into a modern Arab state. Into Yemen's historiographic fabric, he weaves memorable quotes, poetic verses, and first-person accounts, along with an abundance of facts, statistics, maps, and photographs. Dresch points out the paradoxical nature of Yemeni history: the oldest and most ancient of Arab states, Yemen became the first to experiment with democratic elections; and despite all the blood spilled, first in the struggle against the Zaydi Imamate, then later in three civil wars, some would argue that President Ali Abdullah Salih has concentrated power in a way that Imam Yahya never dreamed of, and that the distribution of wealth and influence is more lopsided now than ever. The author warns us that there is much unfinished political business left to transact in the molding of the Yemeni state, and he reminds us that "the country has been there continuously for some millennia, whatever foreigners may have come and gone, and doubtless it will be there a long time yet." In-sha-Allah

Paul Roochnik, Ph.D., Department of Near Eastern Studies, Princeton University 